\title{
THE TRAINING OF RHODESIAN OFFICERS AT THE ROYAL MILITARY ACADEMY, SANDHURST.
}

\author{
* Lt Gen K. R. Coster ICD, OBE
}

The editorial in Militaria 9/1 of 1979 notes that Professor Dale's research with regard to the South African Armed Forces and their link with the United Kingdom and the Commonwealth of Nations, 1910-1961, has revealed that few South Africans ever studied at Sandhurst. On the other hand he observes that Rhodesia has far more Sandhurst-qualified officers.

As an officer who started his military career in the Special Service Battalion to which Professor Dale refers, and who did his officer training originally in South Africa before eventually serving with the Federal Army (of Rhodesia and Nyasaland) and subsequently with the Rhodesian Army, it might be appropriate if I were to commend on this observation.

Unfortunately I have no records available for reference and so must rely upon memory.

\section{Bonds of friendship}

Starting with the fact of Rhodesia having far more Sandhurst trained officers, the reason is, I believe, twofold. In the first place the military, and other bonds between Rhodesia and Great Britain were, until UDI in 1965, much stronger than those between South Africa and Great Britain. What bonds did exist in the latter case were somewhat artificial and did not spring from the same kith and kin relationship which existed between Britain and the colony of Southern Rhodesia prior to and including the period of the Rhodesia and Nyasaland Federation. These bonds were to become very strained as it became evident that Britain was prepared to allow the secession of Northern Rhodesia and Nyasaland from the Federation and was getting ready to grant independence to those territories whilst witholding that rich prize from Southern Rhodesia.

The friendship between Southern Rhodesia and Britain dated from 1890 when the Pioneer Column set out from Macloutsie and made its way to the territory which lay north of the Limpopo River. The first administration of the territory which was to become known as Southern Rhodesia was provided by the British South Africa Company which derived its charter from Queen Victoria.

During the Anglo-Boer War of 1899 to 1902 Rhodesians 'served the Queen'1 as described by Colonel A. S. Hickman in his book of that name. They were again in action from 1914 tot 1918 on the side of the British in the Great War. When the Second World War broke out in 1939 Southern Rhodesia was, I believe, the first of the British colonies to respond to the call to arms by the mother-country and provided proportionately to its population, more soldiers, sailors and airmen than any of the others.

The bonds which are forged in war have, through the course of history, been those which have endured most strongly, based as they are upon the most fundamental of relationships - those between men sharing common dangers and giving their lives for the same cause.

\section{Military affiliations}

The forces of Southern Rhodesia in the years between the conclusion of the Second World War and the establishment of the Federation of the Rhodesias (Northern and Southern) and Nyasaland felt a strong affinity for the forces of the Crown. These bonds were reinforced by affiliations between regiments of the British Army and the Southern Rhodesia forces. For example, the Royal Rhodesia Regiment was affiliated to the Kings Royal Rifle Corps while the Rhodesian African Rifles was affiliated to the South Wales Borderers.

Officers of the Southern Rhodesian forces looked to the United Kingdom for training courses ranging from Drill Instructors to Staff Courses at

* Lt Gen K. R. Coster ICD, OBE joined the Special Service Battalion in
1937, received his commission in 1939 and served in the SA Air 1937, received his commission in 1939 and served in the SA Air

In 1955 he joined the army of the Federation of Rhodesia and Nyasaland. He retired in 1972 as General Officer Commanding'the Rhodesian Army. 
Camberley and Bracknell. Until Southern Rhodesia became part of the Federation, however, there was no call for the training of subaltern officers for the then Southern Rhodesia Staff Corps. The reason was a simple one. When the Second World War ended, commissioned officers streamed back to Southern Rhodesia and many made their way into the armed forces of the colony. Most were expected to relinquish their commissions and revert to the ranks before being re-commissioned, once it was established that they met the high standards demanded by the Permanent Staff Corps.

This permanent corps was essentially a cadre of headquarter and instructional personnel whose function it was to train the territorial or part-time soldiers of the colony. Except for the Rhodesian African Rifles, there were no regular infantry battalions or equivalent units of other arms which required the services of very young subaltern officers for employment as platoon commanders for example. All new commissioned officers were therefore found from among the other ranks already serving in the Southern Rhodesia Staff Corps, most of them having previously been commissioned officers in the British Armed Forces or the forces of the Commonwealth during the war.

It was not until the two Rhodesias and Nyasaland were joined in Federation that regular infantry battalions became part of the order of battle and the need for young subaltern officers was felt. The Federation brought together four infantry battalions which formed the fighting core of the Federal Armed Forces. These were The Northern Rhodesia Regiment, the 1st and 2nd Battalions of the King's African Rifles and the 1st Battalion, The Rhodesian African Rifles. The latter unit was indigenous to Southern Rhodesia whilst the 1st and 2nd Battalions of the King's African Rifles were both found from Nyasaland.

Prior to the establishment of the Federation in 1953, The Northern Rhodesia Regiment and the two battalions of the King's African Rifles were part of East Africa Command with headquarters in Nairobi. East Africa Command (controlled by the British Army) was charged with providing a battalion for counter-insurgency operations against the communist terrorists in Malaya and this responsibility was carried over to the newly formed Central Africa Command which came into being on the establishment of the Federation. In the early days of the Federation the officer complement for the four regular infantry battalions was found by the British Army which seconded regular army officers to Central Africa Command for a tour of duty normally of three years.

\section{Federal army}

It was, however, always the intention that the Federal Army should eventually relieve the British Army of this task and provide its own officers for all the regular units of Central Africa Command. This, as a matter of interest, was accomplished by 1959, six years after the Federation came into being. The last British Army officer went back to Britain and the whole of the Federal Army was officered by men whose loyalty was no longer directly to the Crown but via a Governor-General appointed by the Queen. Many of the Federal Army officers were ex British Army who had resigned and rejoined the Federal forces. The balance was found from ex-officers of the Southern Rhodesia Staff Corps and a number of ex-officers from the Union Defence Force, virtually all of whom had seen service in the Second World War.

\section{Training}

It had become evident at the outset that the Federation would have to provide not only the more senior officers to replace returning British Army officers, but subalterns as well, and it was at that point in time that the idea of training Federal subalterns at the Royal Military Academy, Sandhurst, was conceived. With the exception of the Rhodesian African Rifles, the other infantry battalions had been built on the traditions of the British Army and had (since before the turn of the century in the case of the King's African Rifles) been officered by British Army officers, most of whom had received their officer training at Sandhurst. It was only since the Second World War that Eaton Hall had begun to contribute subaltern officers as well.

The first small batch of Federal Army cadets selected in Rhodesia left for England in 1954 and returned some two years later having achieved the most extraordinary distinction of having won the Sword of Honour and the top Academic Prize. These great distinctions went to Cadet Crutchley and Cadet McKenzie respectively. On their return the newly commissioned officers were posted to regular infantry battalions as platoon commanders.

Regularly each year thereafter a small number of Federal Army cadets left for Sandhurst in order to keep up the flow of subalterns into the infantry 
battalions of Central Africa Command. In point of fact their numbers were inadequate to maintain the requisite total of young officers in these and other units of the Federal Army, and it became necessary, before the dissolution of the Federation, to commence officer training at the School of Infantry located in Southern Rhodesia. The experience gained in training officers locally was to stand Southern Rhodesia in good stead when UDI was declared in 1965, and Great Britain pulled down the shutters as far as any further military training for Rhodesians in that country was concerned. The last Rhodesian cadets to be trained at Sandhurst returned to their own country in November 1965.

\section{Republic of South Africa}

So much then for the reasons for Rhodesia having more Sandhurst-qualified officers than the Republic, as correctly stated by Professor Dale. I believe I would not be wrong if I averred that Rhodesia's Sandhurst-qualified officers exceeded those of the Republic of South Africa by $100 \%$. To the best of my knowledge South Africa has not, nor ever has had any officers trained at Sandhurst. It is possible that Sandhurst-trained officers have served in the South African forces at one time or another, especially during the World Wars, but it has never been South African policy to send cadet officers to the Royal Military Academy in the same way that Southern Rhodesia and the Federation did.

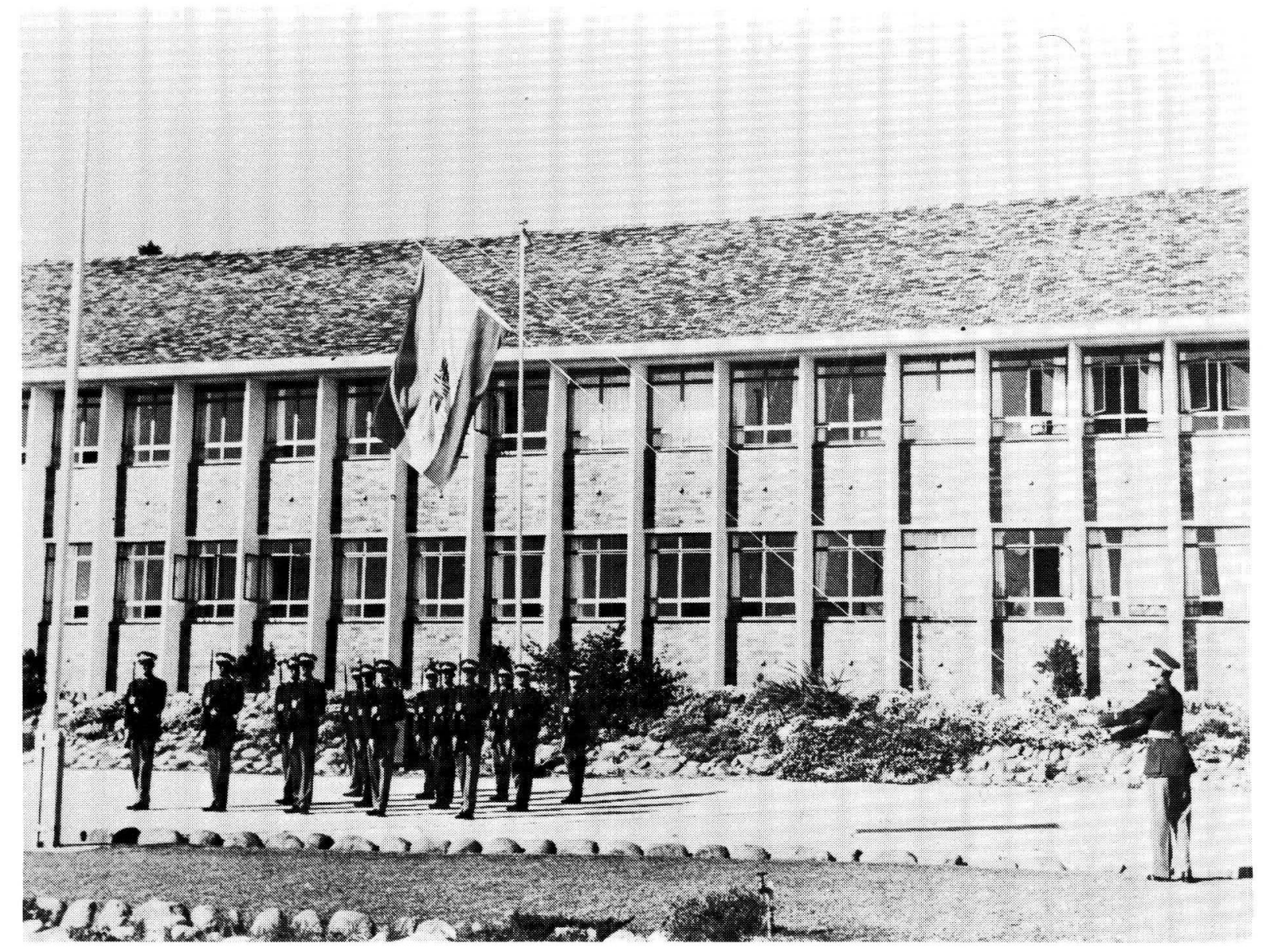

South African Military Academy: Saldanha 
The reasons for this are the reverse of the reasons why Southern Rhodesia did. In the first place, as mentioned earlier, South Africa never had the same sort of kith and kin relationship with Great Britain; rather the reverse in fact. The two countries had been actively hostile as recently as 1902 when the Second Anglo-Boer War ended, and the relationships which were established thereafter were, if not fragile, certainly not based upon blood ties as in the case of Southern Rhodesia. They were in fact somewhat artificial although they were to endure until 1961 when South Africa eventually left the Commonwealth and became a sovereign independent Republic.

Nevertheless, fairly strong military bonds were established and built up between the two countries which only a short time before, had been at war with each other. South Africa, in spite of some internal opposition, went to war again in 1914 on the side of Great Britain and made considerable sacrifices in terms of lives in the war to end wars.

In the years between the First and Second World Wars, these military bonds grew stronger as the bitterness engendered by the Second AngloBoer War was replaced by the friendships which grew out of the active service which had been the common lot of Boer and Briton between 1914 and 1918, now fighting together instead of against each other. Between the two wars we find that the Union Defence Force leant fairly heavily upon the British military establishment for the sort of training which it would have been difficult to provide in South Africa. Union Defence Force officers, essentially Army and Air Force officers, as well as other ranks of those two services attended courses in Great Britain ranging from Drill Instructors to Staff Courses.

\section{British millitary influence}

No British Army or Royal Air Force personnel, as far as I am aware, attended courses in the Union of South Africa on a reciprocal basis, but the British military influence made itself felt in Union Defence Force circles by the secondment of instructors from Britain. On my own cadet course at the South African Military College, one of our officer instructors was a Captain RobertsonGlascow of the British Army, and I recall a Colour-Sergeant from the Scots Guards whose voice carried well beyond the confines of the drill square at the Military College. More well known were officers like Major George Bastin, later to become Major General Bastin of the Royal
Artillery and Major M. C. Dempsey, MC, who rose to fame in the Second World War as General Sir Miles Dempsey. There were also seconded personnel from the Royal Air Force right up to the commencement of the Second World War. The war itself brought hundreds of British Army, Royal Air Force and Royal Navy personnel to the Union on secondment.

The extraordinary fact, however, about the exchange of Union Defence Force and British military personnel between the two wars is that, as professor Dale's research revealed, no young South Africans were sent to Britain for officer training. What were the reasons for this? In my view there were two chief reasons and I offer them in reverse order of priority. Firstly, the facilities and the instructors for officer training were avilable in the Union. Secondly, a young man is at his most impressionable between the ages of eighteen and twenty-one, and it is at this age that the foundation is laid for a life time in the profession of arms. It is important, therefore, to inculcate loyalty to the country and the service in which the young officer will spend the rest of his professional life. Once cast in the correct mould it is unlikely that his approach to his chosen career will deviate to any significant extent from that which was considered initially desirable.

\section{SA Military College}

Between 1918 and 1939 many hundreds of young South Africans underwent their officer training at the South African Military College. The course which latterly at any rate, lasted two years, was designed to produce an individual capable of taking his place as an officer in the South African Artillery or the South African Air Force. Infantry training was also conducted but pride of place went to artillery and air force training for the reason that the South African Permanent Force of those days consisted essentially of those two arms/services. There was virtually no academic training for officer cadets at that time and the course was based upon the text books of the military arms of the services. The emphasis was laid more upon the so-called officer qualities of leadership, loyalty, discipline, courage, determination and the like. Turnout, smartness on parade, the ability to ride a horse or lay a gun, to fly an aircraft and indeed to carry one's liquor and comfort oneself properly in an officers mess were considered more important than academic achievement.

Many of the instructional personnel both commissioned or non-commissioned had re- 
ceived some form of training with the British Army of the Royal Air Force and consequently many of the purely British traditions were carried over into the South African Permanent Force. South African officer cadets felt no envy for their counterparts at Sandhurst. In fact they considered themslves infinitely superior as they were learning to be gunners and pilots as well as receiving a basic infantry training. At Sandhurst no artillry or air force training was given.

\section{Sandhurst}

It was natural that after the end of the Second World War, South Africa should revert initially to the same type of officer cadet training that had been in vogue when the war started, but it was not long before it became apparent that a new era had been ushered in by the war itself. The use of the Royal Military Academy, Sandhurst, was not at any stage after the war considered as an alternative to local training. No doubt the British Army would have been prepared to accept South Africans for training at Sandhurst as they did at all their other military institutions, but the reasons for not using Sandhurst before the war were still valid.
Any possibility that South Africa might have requested Britain to accept its officer cadets for training at Sandhurst finally fell away for ever when South Africa made the decision to leave the Commonwealth, just as four years later Southern Rhodesia's military ties with what had been the mother country were severed by the act of UDI.

I trust that I have been able to answer the observation why few South Africans ever studied at Sandhurst while the Rhodesian Forces by comparison contain a fair number of Sandhurstqualified officers.

Since Rhodesia as a country no longer exists and since the Republic of South Africa is now completely self-sufficient as regards military training, the question can never again be of more than academic interest.

\section{FOOT-NOTES}

1. A. S. Hickman, MBE, C St J, QPM, Rhodesia Served the Queen, (Published by Authority of the Government of Rhodesia, 1970). 